\author{
Łukasz Jurek \\ Katolicki Uniwersytet Lubelski Jana Pawła II \\ Bogusław Przywora \\ Akademia im. Jana Długosza w Częstochowie \\ bprzywora@op.pl
}

\title{
Glosa do wyroku Trybunału Konstytucyjnego z dnia 13 listopada 2012 r., sygn. akt K 2/12*
}

W glosowanym orzeczeniu Trybunał Konstytucyjny (dalej: Trybunał lub TK) - na skutek skierowanego przez grupę senatorów wniosku - poddał kontroli konstytucyjności art. 28 ustawy z dnia 16 grudnia 2010 r. o zmianie ustawy o finansach publicznych oraz niektórych innych ustaw ${ }^{1}$; w związku z art. 103 a ustawy z dnia 17 grudnia 1998 r. o emeryturach i rentach z Funduszu Ubezpieczeń Społecznych ${ }^{2}$, dodanym przez art. 6 pkt 2 ustawy z 16 grudnia 2010 r. w zakresie, w jakim znajduje zastosowanie do osób, które nabyły prawo do emerytury przed dniem 1 stycznia 2011 r. bez konieczności rozwiązania stosunku pracy, orzekł, iż regulacja ta jest niezgodna z zasadą ochrony zaufania obywatela do państwa i stanowionego przez nie prawa wynikającą $\mathrm{z}$ art. 2 Konstytucji Rzeczypospolitej Polskiej.

Podejmując problematykę wskazaną w przedmiotowym orzeczeniu, konieczne jest $\mathrm{w}$ pierwszej kolejności przedstawienie wytycznych w zakresie zabezpieczenia społecznego wynikających z Konstytucji RP. ${ }^{3}$ Przepis art. 67 ust. 1 ustawy zasadniczej wyraźnie stanowi, że każdy obywatel ma prawo do zabezpieczenia społecznego w razie niezdolności do pracy ze względu na chorobę lub inwalidztwo oraz po osiągnięciu wieku emerytalnego. Generalnie rzecz ujmując, artykuł ten mówi o zabezpieczeniu społecznym, na które składa się całokształt świadczeń,

\footnotetext{
* Sentencja została ogłoszona dnia 22 listopada 2012 r. w Dz. U. z 2012 r., poz. 1285.

${ }^{1}$ Dz. U. nr 257, poz. 1726 , z późn. zm.

${ }^{2}$ Dz. U. z 2009 r. nr 153, poz. 1227, z późn. zm.

${ }^{3}$ Konstytucja Rzeczypospolitej Polskiej z dnia 2 kwietnia 1997 r. (Dz. U. nr 78, poz. 483).
} 
jakie ze środków publicznych mogą być przekazane obywatelom spełniającym przesłanki do uzyskania świadczenia. ${ }^{4}$ Słusznie zauważa L. Garlicki ${ }^{5}$, że zabezpieczenie ujęte zostało jako prawo podmiotowe, a rangę tego prawa dodatkowo podkreślono, nadając mu w pełni egzekwowalny charakter. Jednocześnie należy dostrzec, iż ograniczenie zakresu dochodzenia praw socjalnych określonych w art. 81 Konstytucji RP nie odnosi się do zabezpieczenia społecznego. ${ }^{6}$ Podmiotem tego prawa jest każdy obywatel, zaś adresatem obowiązków są władze publiczne. ${ }^{7}$ Artykuł 67 wyraża zatem nakaz ustanowienia określonego systemu zabezpieczenia społecznego i sposobu jego finansowania. ${ }^{8}$ Jednocześnie należy zauważyć, iż artykuł ten ma znaczenie odsyłające, gdyż problem zakresu i form zabezpieczenia społecznego pozostawiono ustawodawcy zwykłemu. ${ }^{9}$ Otwartą kwestią więc pozostaje określenie granicy wieku emerytalnego.

Treścią ryzyka emerytalnego było zatem nie samo osiągnięcie wieku emerytalnego, lecz prawo do zaprzestania świadczenia pracy po osiągnięciu wieku emerytalnego. ${ }^{10}$ Od 1991 r. do nabycia prawa do świadczenia emerytalnego nie była już konieczna rezygnacja ze świadczenia pracy, natomiast od 2000 r. brak rozwiązania stosunku pracy skutkował zawieszeniem prawa do świadczenia emerytalnego niezależnie od osiąganych z tego tytułu zarobków. Następnie treść ryzyka emerytalnego ulegała dalszym zmianom i obecnie znów rozwiązanie stosunku pracy jest niezbędne do uzyskania prawa do wypłaty świadczenia emerytalnego. To ryzyko ziszcza się, gdy ubezpieczony dożyje wieku emerytalnego i rozwiąże stosunek pracy, choćby nawet w kolejnym dniu został on ponownie nawiązany. Jednocześnie trudno podzielić stanowisko prezentowane przez K. Antonowa ${ }^{11}$, że takie podejście zostało przesądzone w art. 1 ustawy o systemie ubezpieczeń społecznych. ${ }^{12}$ Przedmiotowy przepis wskazuje jedynie, że ubezpieczenie emerytalne jest jednym z elementów ubezpieczeń społecznych, nie traktuje zaś o treści ryzyka emerytalnego. Zbyt daleko też idzie w swoim wywodzie P. Kostrzewa, wskazu-

${ }^{4}$ Wyrok TK z 20 listopada 2001 r., K 15/01 OTK ZU 2001, nr 8, poz. 252.

${ }^{5}$ L. Garlicki, Komentarz do art. 67 Konstytucji RP, [w:] L. Garlicki, Konstytucja Rzeczypospolitej Polskiej. Komentarz, Warszawa 2007, s. 3.

${ }^{6}$ L. Garlicki, op. cit., s. 3; K. W. Baran, Sposób ujęcia i charakter regulacji konstytucyjnych wolności i praw dotyczacych pracy, [w:] K.W. Baran (red.), Zarys systemu prawa pracy, t. I: Część ogólna prawa pracy, Warszawa 2010 [dostęp: 14.11.2014 r.]; w orzecznictwie w szczególności wyrok TK z 8 maja 2000 r. SK 22/99, OTK ZU 2000, nr 4, poz. 107.

${ }^{7}$ L. Garlicki, op. cit.; s. 3-4.

${ }^{8}$ Ibidem.

${ }^{9}$ W. Skrzydło, Komentarz do art. 67 Konstytucji Rzeczypospolitej Polskiej, LEX/el, 2013.

${ }^{10}$ I. Jędrasik-Jankowska, Treść ryzyka emerytalnego, [w:] T. Bińczycka-Majewska, Konstrukcje prawa emerytalnego, Wyd. Zakamycze, Kraków 2004, s. 75-76.

${ }^{11}$ Por. K. Antonów, Prawo do emerytury, Wyd. Zakamycze, Kraków 2003, s. 17.

${ }^{12}$ Ustawa z dnia 13 października 1998 r. o systemie ubezpieczeń społecznych ( Dz. U. z 2013 r., poz. 1442 z późn. zm.). 
jąc, że zabezpieczenie emerytalne chroni przed ryzykiem starości, z którym wiąże się zakończenie działalności zarobkowej. ${ }^{13}$ Ustawodawca co do zasady wymagał bowiem jedynie, aby w momencie nabycia prawa do świadczenia emerytalnego w celu jego wypłaty ubezpieczony zakończył dotychczasową aktywność zawodową. Nie ograniczał on natomiast ewentualnej możliwości podjęcia aktywności zawodowej przez osoby pobierające świadczenia emerytalne.

Konstytucja RP - jak już sygnalizowano - pozostawia ustawodawcy zwykłemu określenie granicy wieku emerytalnego. Jednakże granica ta nie może być określana w sposób dowolny, należy mieć na uwadze sytuację na rynku pracy, stan zdrowia ubezpieczonych oraz ich faktyczne kwalifikacje. Faktem jest, że wydłuża się średnia długość życia, natomiast maleje liczba osób opłacających składki na ubezpieczenia społeczne, co powoduje zmniejszenie wpływów do Funduszu Ubezpieczeń Społecznych. Wydaje się, iż zjawisko to dodatkowo będzie się nasilać w wyniku drastycznie spadającego poziomu przyrostu naturalnego. I tu rozwiązaniem jest dookreślenie ryzyka emerytalnego, wyróżniając obok wieku także przesłankę braku faktycznej możliwości kontynuowania działalności zarobkowej, choćby ze względów zdrowotnych, albo też dalsze podwyższanie granicy wieku emerytalnego. Analizując aktualną sytuację finansów publicznych, trudno uciec od refleksji, że obecny system będzie trudny do utrzymania, ale ustawodawca w pierwszej kolejności powinien chronić osoby najsłabsze. Sytuacja polegająca na tym, że Fundusz Ubezpieczeń Społecznych zaciąga kolejne zobowiązania finansowe, natomiast świadczeniobiorcy kontynuują działalność zarobkową, jest nie do utrzymania z uwagi na stan finansów publicznych. Jest też niesprawiedliwa wobec ubezpieczonych, którzy ten system finansują. Warto przy tym przypomnieć, że obecne świadczenia nie oddają wprost wysokości odprowadzonych składek, a są jedynie rezultatem woli ustawodawcy. Aktualny system zabezpieczenia uzależnia wprost wysokość świadczenia emerytalnego od wpływów na indywidualne konto ubezpieczonego, przy czym należy zauważyć, że te świadczenia są wyraźnie niższe.

Często w środkach masowego przekazu pojawia się argument, że emerytura została przez świadczeniobiorców wypracowana, ale tak będzie dopiero w przypadku emerytów urodzonych po 31 grudnia 1968 r., którzy będą pobierać wyłącznie świadczenia z nowego systemu. Te wywody są o tyle istotne, że Trybunał Konstytucyjny, który dostrzega w swoich orzeczeniach kondycję finansów publicznych, musiał pochylić się tak naprawdę w istotnej części nad osobami zatrudnionymi w sektorze publicznym, które osiągnęły wiek emerytalny i chciały zarówno kontynuować działalność zawodową, jak i pobierać świadczenie emerytalne. Abstrahując już od samego przedmiotu sprawy, zauważyć należy, że w przypadku

${ }^{13}$ P. Kostrzewa, Komentarz do art. 1 ustawy o systemie ubezpieczeń społecznych, LEX/el, 2014. 
tych osób ukazuje się w całej pełni wadliwość obecnego systemu. Osoby pracujące w sferze budżetowej, bo w istocie to ich dotyczyła przedmiotowa sprawa, osiągające stałe i pewne dochody, danego dnia kończą określony wiek przez ustawodawcę, i to zdaniem ustawodawcy wiąże się z wystąpieniem ryzyka. W doktrynie słusznie mówi się właściwie już tylko o pojęciu ryzyka dożycia wieku emerytalnego. W tym kontekście faktycznie pojęcie ryzyka emerytalnego jest nieadekwatne.

Trzeba jednocześnie zauważyć, że skutkiem wystąpienia ryzyka emerytalnego jest poprawa sytuacji ubezpieczonych. Obok wynagrodzenia za pracę otrzymują oni bowiem także świadczenie emerytalne. Konieczność rozwiązania stosunku pracy wiązałaby się bowiem z przystąpieniem do konkursu na wolne stanowisko pracy - zgodnie z zasadami naboru do służby publicznej..$^{14}$ Analizując społeczny kontekst glosowanego wyroku, należy zatem zauważyć, że dotyczył on w dużej części osób, które w większości nie można uznać za znajdujące się w trudnej sytuacji materialnej.

Poczynione uwagi wprowadzające stanowią podstawę do podjęcia próby oceny rozstrzygnięcia przyjętego przez TK w przedmiotowej sprawie. Problem sprowadza się do tego, czy ustawodawca mógł na podstawie art. 28 ustawy z dnia16 grudnia 2010 r. o zmianie ustawy o finansach publicznych oraz niektórych innych ustaw (Dz. U. nr 257, poz. 1726 z późn. zm.) rozciągnąć stosowanie art. 103 a ustawy o emeryturach i rentach z FUS - przepisu ustalającego nową treść ryzyka emerytalnego - na sytuacje przeszłe, tj. wobec osób, które już nabyły prawo do emerytury w okresie od 8 stycznia 2009 r. do 31 grudnia 2010 r., czyli w czasie obowiązywania regulacji niezawierającej wymogu rozwiązania stosunku pracy z dotychczasowym pracodawcą dla uzyskania świadczenia emerytalnego. Na podstawie art. 28 ustawy zmieniającej z 16 grudnia 2010 r. prawo do emerytury tych osób ulega zawieszeniu, począwszy od 1 października 2011 r., jeżeli nie rozwiążą stosunku pracy do 30 września 2011 r. Trybunał, oceniając sytuację osób, które nabyły i zrealizowały prawo do emerytury w okresie od 8 stycznia 2009 r. do 31 grudnia $2010 \mathrm{r}$., z punktu widzenia zasady ochrony zaufania do państwa i stanowionego przez nie prawa oraz bezpieczeństwa prawnego obywateli, doszedł do wniosku, ,że gdyby w momencie przejścia na emeryturę osoby te wiedziały, iż będą musiały przerwać zatrudnienie, aby uzyskać świadczenie emerytalne, to w chwili osiągnięcia wieku emerytalnego zrezygnowałyby ze złożenia wniosku o ustalenie prawa do emerytury i kontynuowałyby zatrudnienie. Korzystniejsze dla nich byłoby bowiem uzyskiwanie wysokiego dochodu ze stosunku pracy niż dużo mniejszego świadczenia emerytalnego". ${ }^{15}$ Zdaniem TK, „działając w zaufaniu do pań-

${ }^{14}$ B. Przywora, Transformacje ustrojowe polskiej stużby cywilnej, Kraków 2012, s. 149 i n.

${ }^{15}$ Uzasadnienie do orzeczenia TK z dnia 13 listopada 2012 r., sygn. akt. K 2/12, http://trybunal. gov.pl/s/k-212/. 
stwa i stanowionego przez nie prawa, ubezpieczeni podjęli w przeszłości decyzję co do przejścia na emeryturę. Gdyby wiedzieli, że nastąpi zmiana stanu prawnego, uzależniająca realizację prawa do świadczenia emerytalnego od uprzedniego rozwiązania stosunku pracy, ich decyzja mogła być inna, bo z perspektywy dokonanej nowelizacji ustawy o emeryturach i rentach z FUS i objęcia nią także tych osób, okazała się dla nich niekorzystna". ${ }^{16}$ TK stwierdził, iż „dokonana przez ustawodawcę zmiana, polegająca na dodaniu do ustawy o emeryturach i rentach z FUS art. 103a, dotyczy niezwykle ważnej z punktu widzenia nabycia prawa do emerytury kwestii, jaką jest treść ryzyka emerytalnego. W tym kontekście, jeśli ubezpieczony już raz te warunki skutecznie spełnił (na gruncie rozpatrywanej sprawy - osiągnął wiek emerytalny i odpowiedni staż pracy - bo taka była treść ryzyka emerytalnego dla osób, które przeszły na emeryturę od 8 stycznia 2009 r. do 31 grudnia $2010 \mathrm{r}$.), to niedopuszczalne jest $-\mathrm{z}$ punktu widzenia zasady ochrony zaufania do państwa i stanowionego przez nie prawa - nakazanie mu zastosowania się do nowej treści ryzyka, czyli nakazanie mu ponownego zrealizowania już raz skutecznie zrealizowanego prawa do emerytury. Osoby, o których mowa, podjęły decyzję o przejściu na emeryturę, nie mogąc przewidzieć, że przepisy zmienią się na ich niekorzyść. W przeciwnym wypadku nie składałyby one wniosku o ustalenie prawa do świadczenia emerytalnego, bo korzystniejsze byłoby dla nich pobieranie wynagrodzenia niż dużo mniejszej emerytury, o którą wystąpiłyby po ustaniu zatrudnienia i która wówczas byłaby wyższa niż ta wyliczona w chwili, gdy złożyły wniosek po osiągnięciu wieku emerytalnego". ${ }^{17}$

Jednocześnie należy podkreślić, iż wyżej wspomniane stanowisko TK nie zostało przyjęte przez wszystkich sędziów TK. Krytyczna ocena rozstrzygnięcia wyrażona została w zdaniach odrębnych. I tak, w zdaniu odrębnym sędzia TK A. Rzepliński stwierdził, iż „uzasadnienie wyroku w niniejszej sprawie wychodzi z odmiennych założeń niż wyrok w tożsamej konstytucyjnie sprawie o sygn. SK 45/04 (tam możliwość równoczesnego zatrudnienia i pobierania emerytury została uznana - słusznie - za przywilej, który nie mieści się w uzasadnionych konstytucyjnie oczekiwaniach jednostki)" ${ }^{18}$ Jego zdaniem Trybunał ,zignorował rozumowanie zawarte w sprawie o sygn. SK 45/04 i wypowiada się o treści art. 103 a ustawy emerytalnej z pominięciem zawartych tam ustaleń”. Dlatego też zaproponował jako właściwsze rozwiązanie ,przekazania sprawy do rozstrzygnięcia pełnemu składowi Trybunału". Problem w tym - na co słusznie zwraca uwagę sędzia TK A. Rzepliński - iż po glosowanym wyroku ,ustawodawca $\mathrm{w}$ tożsamym przedmiocie regulacji otrzymuje dwa komunikaty: o konstytucyjności (sprawa o sygn. SK 45/04) oraz o niekonstytucyjności tej samej normy (spra-

\footnotetext{
${ }^{16}$ Ibidem.

${ }^{17}$ Ibidem.

${ }^{18}$ Ibidem, s. 25.
} 
$128 \longrightarrow$ Glosy

wa o sygn. $\mathrm{K}$ 2/12) konfrontowanej z treścią tego samego wzorca: wynikającej z art. 2 Konstytucji zasady ochrony zaufania obywatela do państwa i stanowionego przez nie prawa". ${ }^{19}$ Zgodzić się należy ze stanowiskiem sędziego Rzeplińskiego, iż TK „nie wykazał, dlaczego kontrolowana modyfikacja treści ryzyka emerytalnego jest na tyle istotna, że narusza zasadę ochrony zaufania obywateli do państwa i stanowionego przez nie prawa wynikającą z art. 2 Konstytucji"” ${ }^{20}$ Sędzia stoi na stanowisku, że pobieranie emerytury wraz z jednoczesnym zatrudnieniem jest „przywilejem wykraczającym poza treść prawa do zabezpieczenia społecznego wynikającym z art. 67 ust. 1 Konstytucji". ${ }^{21}$ Ponadto zasadne wydaje się twierdzenie ww. sędziego TK, iż zakwestionowany, art. 28 ustawy z 16 grudnia 2010 r. w związku z art. 103 a ustawy emerytalnej, dodanym przez art. 6 pkt 2 ustawy z 16 grudnia 2010 r., w zakresie, w jakim znajduje zastosowanie do osób, które nabyły prawo do emerytury przed 1 stycznia 2011 r., bez konieczności rozwiązania stosunku pracy, nie narusza zatem istoty konstytucyjnego prawa do zabezpieczenia społecznego i nie pozbawia wymaganego przez Konstytucję minimum życiowego osób, które osiągnęły wiek emerytalny". ${ }^{22} \mathrm{~W}$ świetle powyższego brak było podstaw do przyjęcia, że kwestionowane przez wnioskodawcę rozwiązanie godziło w zasadę zaufania obywateli do państwa i stanowionego przez nie prawa. Należy bowiem mieć na względzie - na co zwraca uwagę sędzia TK A. Rzepliński - że ubezpieczony musi mieć świadomość, iż „ustawodawca, prowadząc określoną politykę społeczną, może ograniczyć zakres tego przywileju, ze względu na interes publiczny. [...] Ustawodawca może brać pod uwagę sytuację, że dla części emerytów emerytura stanowi tylko uzupełniające źródło dochodów. Nie można zatem mówić o ich ograniczonej zdolności adaptacyjnej”. ${ }^{23}$

Podkreślić należy, iż przyjętego w glosowanym orzeczeniu poglądu Trybunału nie podzielił również sędzia TK P. Tuleja, który w zdaniu odrębnym zasadnie stwierdził, że w sprawie o sygn. SK 45/04 i w sprawie podejmowanej w glosowanym orzeczeniu mamy do czynienia z odmiennym przedmiotem zaskarżenia ${ }^{24}$, bowiem $\mathrm{w}$ pierwszym $\mathrm{z}$ nich TK zajmował się przede wszystkim dopuszczalnością równoczesnego pobierana świadczenia emerytalnego i wynagrodzenia za pracę, ale dokonał też oceny kwestii intertemporalnej, natomiast w sprawie podejmowanej w glosowanym orzeczeniu ,ingerencja państwa dotyka ubezpieczonego, który nabył prawo do emerytury i postanowił nie rozwiązywać stosunku pracy $\mathrm{z}$ dotychczasowym pracodawcą. Przedmiotem ingerencji jest wyłącznie prawo

\footnotetext{
${ }^{19}$ Ibidem.

${ }^{20}$ Ibidem.

${ }^{21}$ Ibidem.

${ }^{22}$ Ibidem.

${ }^{23}$ Ibidem, s. 27.

${ }^{24}$ Ibidem, s. 28.
} 
do emerytury pobieranej łącznie $\mathrm{z}$ wynagrodzeniem za pracę $\mathrm{u}$ dotychczasowego pracodawcy”. ${ }^{25}$ Słusznie dostrzegł sędzia P. Tuleja, iż „ingerencja ustawodawcy nie polega na zniesieniu nabytego prawa do emerytury ani na zmniejszeniu jego zakresu, ale na wprowadzeniu dodatkowych warunków jego realizacji. [...] możliwość pobierania świadczeń emerytalnych bez przerwania działalności zawodowej u dotychczasowego pracodawcy stanowi przywilej, który wykracza poza powszechnie przyjmowane pojęcie ubezpieczenia społecznego". ${ }^{26} \mathrm{~W}$ jego przekonaniu TK „nie tylko nie dostrzegł tożsamości przedmiotowej obu spraw, ale na tle identycznego problemu konstytucyjnego wyprowadził odmienne wnioski niż te, które wynikają z wyroku wydanego 7 lutego 2006 r.”, bowiem „w wyroku tym został wyrażony pogląd, w myśl którego Konstytucja nie gwarantuje równoczesnej realizacji prawa do emerytury i kontynuowania zatrudnienia. Prawo do kontytuowania zatrudnienia wynika wyłącznie z ustawy i może zostać ograniczone również w stosunku do osób, które prawo do emerytury nabyły wcześniej”, zaś w glosowanym orzeczeniu Trybunał „wyraził pogląd przeciwny i stwierdził, że z zasady zaufania wynika zakaz zmiany ryzyka emerytalnego w stosunku do osób, które nabyły prawo do emerytury pod rządami przepisów, które nabycia tego prawa nie uzależniały od zaprzestania zatrudnienia". ${ }^{27} \mathrm{~W}$ końcowej części rozważań sędzia P. Tuleja zasadnie wyprowadził wniosek, iż „Z art. 67 ust. 1 Konstytucji wynika wyłącznie prawo do emerytury po osiągnięciu określonego wieku” zaś „kwestię uzależnienia nabycia tego prawa od braku równoczesnego zatrudnienia Konstytucja pozostawia w gestii ustawodawcy zwykłego, co wprost wynika ze zdania drugiego tego przepisu. Dlatego osoba, która nabyła prawo do emerytury, kontynuując równocześnie zatrudnienie, nie może oczekiwać, że przywilej ten będzie jej gwarantowany przez cały czas pobierania świadczenia emerytalnego. Tym samym nie można przyjąć, że wprowadzone przez ustawodawcę $\mathrm{w}$ art. 28 zaskarżonej ustawy ograniczenie zaskakiwało obywateli i naruszało zaufanie obywatela do państwa. Ponieważ prawo równoczesnego pobierania emerytury i wykonywania pracy nie wynika z zasady zaufania obywatela do państwa, nie można w oparciu o tę zasadę stosować testu proporcjonalności z art. 31 ust. 3 Konstytucji". ${ }^{28} \mathrm{~W}$ świetle tych argumentów sędzia TK P. Tuleja za bezprzedmiotowe uważa „rozważania Trybunału Konstytucyjnego o nieadekwatności użytego środka do celu wskazanego przez ustawodawcę". ${ }^{29}$

Trudno odmówić trafności spostrzeżeń zawartych w zdaniach odrębnych do glosowanego wyroku, który - bez żadnych przesłanek - stanowi wyłom w do-

\footnotetext{
${ }^{25}$ Ibidem.

${ }^{26}$ Ibidem.

${ }^{27}$ Ibidem.

${ }^{28}$ Ibidem

${ }^{29}$ Ibidem, s. 29.
} 
tychczasowej linii orzeczniczej oraz budzi wątpliwości w odniesieniu do założeń systemu zabezpieczenia emerytalnego. Słusznie podniósł sędzia TK A. Rzepliński, że Trybunał w żaden sposób nie wykazał, dlaczego kontrolowana modyfikacja treści ryzyka emerytalnego ma naruszać zasadę ochrony zaufania obywateli do państwa i stanowionego przez nie prawa, skoro - w przekonaniu autorów trudno mówić w przedmiotowym przypadku o zaskoczeniu tą regulacją świadczeniobiorców. Ustawodawca dał im wystarczająco dużo czasu, aby mogli się przygotować na zmianę swojej sytuacji materialnej, tym bardziej, że - jak wykazano wyżej - trudno w istocie mówić o wystąpieniu w przypadku tych osób ryzyka emerytalnego. Ustawodawca natomiast - jak słusznie zauważył sędzia Tuleja ani nie ograniczył nabytego już prawa do emerytury, ani też nie ograniczył jego zakresu, ale wprowadził dodatkowe warunki jego realizacji. Zgodzić należy się $\mathrm{z}$ tezą, że osoby o zabezpieczonym statusie materialnym nie mają prawa oczekiwać przyznania im dodatkowego przywileju, czyli możliwości kontynuowania zatrudnienia przy zachowaniu prawa do wypłaty świadczenia emerytalnego. Osoba posiadająca prawo do świadczenia emerytalnego w każdej chwili mogła zrezygnować z zatrudnienia, co wiązałoby się - nawet czysto teoretycznie - z wystąpieniem ryzyka emerytalnego. Nie byłoby też żadnych przeszkód, aby osoba ta podjęła dodatkowo zatrudnienie już nabywając prawo do wypłaty świadczenia emerytalnego. Ustawodawca nie wyklucza bowiem dalszej aktywności zawodowej na emeryturze, ale $\mathrm{w}$ większości obowiązujący stan prawny słusznie wiązał wystąpienie ryzyka emerytalnego z koniecznością rezygnacji z zatrudnienia. Jak wskazano już wyżej, ustawodawca posiada ograniczone środki finansowe, dlatego słusznie zauważa sędzia Tuleja, że to interes publiczny może stać się przyczynkiem do wprowadzenia bardziej surowych wymogów realizacji prawa do emerytury.

Wyrok TK został przez ustawodawcę zrealizowany, jednakże warto w tym miejscu podnieść jeszcze jedną wątpliwość. Ubezpieczeni, którzy zrezygnowali z zatrudnienia, czyli dostosowali się do woli ustawodawcy, są w sposób rażący pokrzywdzeni. Ubezpieczeni, którzy zignorowali powszechnie obowiązującą normę prawną, mocą ustawy otrzymały prawo do rekompensaty, natomiast te osoby, które dostosowały się do woli ustawodawcy, muszą swoich roszczeń dochodzić na drodze cywilnej indywidualnie. TK, wydając określone orzeczenia, musi brać pod uwagę wszystkie skutki wyroku, także mieć na uwadze szacunek dla prawa i budowanie go wśród obywateli. Za działanie zgodne z prawem nikt nie powinien być karany, tak jak stało się to w przedmiotowej sprawie. Z powyższych względów trudno uznać glosowane orzeczenie za trafne, natomiast podzielić należy prezentowane stanowiska zawarte w zdaniach odrębnych przez sędziów TK A. Rzeplińskiego i P. Tuleję. 
Pobrane z czasopisma Studia Iuridica Lublinensia http://studiaiuridica.umes.pl Data: 26/04/2023 17:01:46

Ł. Jurek, B. Przywora, Glosa do wyroku Trybunału Konstytucyjnego...

Konkludując, należy stwierdzić, iż warunkiem nabycia prawa do świadczenia emerytalnego musi być wystąpienie ryzyka i w przekonaniu autorów, niezbędny jest chociażby dzień braku świadczenia pracy, tak aby można było chociaż hipotetycznie mówić o wystąpieniu tegoż ryzyka. Jak się wydaje, konieczne będzie dalsze zaostrzenie treści ryzyka emerytalnego. Procesy demograficzne mają bowiem jednoznaczny trend i niezbędną koniecznością stanie się ograniczanie wydatków na świadczenia emerytalne finansowane ze środków publicznych, w szczególności wobec tych osób, dla których nie stanowią one jedynego źródła przychodów. 